\title{
SOME NEW SPECIES OF THE GENUS LONCHÆA \\ (DIPTERA, LONCHAIDA).
}

\author{
BY J. R. MALLOCH,
} Uabana, Ill.

\section{Lonchæa major, sp. n.}

Male.-Shining black, with a slight bluish tinge. Antennæe and palpi black; arista yellowish at base. Legs pitchy black, the hind tarsi hardly paler than their tibix. Wings hyaline, veins brownish yellow, whitish at bases. Calyptræ white, fringes concolorous except at junction of upper and lower, where there are some long, black, setulose hairs. Halteres black.

Eyes bare; frons about twice as long as wide, parallel-sided, surface with short, moderately dense hairs; upper orbits slightly rugose above, bare; frontal lunule hairy; longest hairs on arista over twice as long as its basal diameter; third antennal segment about four times as long as its width, extending to mouth margin. Scutellum with setulose hairs on margins and between apical bristles. the disc bare; pteropleura bare; no hairs adjacent to the stigmatal bristle. Abdomen broad, with rather dense, short, setulose hairs on dorsum; fourth tergite about 1.5 as long as third. Hind femur without distinct anteroventral bristles. Auxiliary vein almost fused with first at its apex.

Length $6.5 \mathrm{~mm}$.

Type.-Amazon, South America. Type in British Museum.

Lonchæa nigrocærulea, sp. n.

Male.-Blue-black, almost metallic in colour. Antennæ and palpi black; arista pale at base; upper orbits and ocellar triangle glossy. Legs black. Wings, calyptræ, and halteres as in major.

Frons about 1.5 as long as wide, sparsely hairy; upper orbits highly glossy smooth; third antennal segment about four times as long as wide, extending below mouth margin; arista as in major; palpi dilated, slightly protruded. Praescutellar acrostichals very long; scutellum as in major; pteropleura bare; no bristly hairs adjacent to stigmatal bristle. Abdomen with longer hairs than in major, especially at apex of fourth tergite; fourth tergite about twice as long as third. Venation as in major, but the antepenultimate section of fourth vein is only two-thirds as long as penultimate, whereas in major it is threefourths as long. Hind femur with a few distinct anteroventral bristles.

Length $4 \mathrm{~mm}$.

Type.-Barbados (E. F. Becher). Type in British Museum.

\section{Lonchæa striatifrons, sp. n.}

Male.-Glossy steel-blue, the abdomen paler than the thorax. Frons shining black, ocellar spot and upper orbits glossy blue; third antennal segment reddish at base below. Legs black, tarsi with the exception of the apical two or three segments reddish testaceous. Wings clear, yellow at bases. Calyptræ white, fringes concolorous. Halteres black.

Frons less than twice as long as wide at anterior margin, not distinctly November, 1920 
narrowed anteriorly, the surface of interfrontalia finely striate on upper half laterally; orbits narrow, distinctly separated from ocellar triangle posteriorly their surfaces microscopically diagonally striate anteriorly; hairs on frons short and sparse; third antennal segment three times as long as wide; cheek narrow, without dense hairs or strong bristles. Thorax as in poliix Say. Basal abdominal sternite with some hairs on each side. Legs and wings as in polita. Fringes of calyptræ longer than usual, about six of the hairs at apex of the fold setulose and longer than the calyptra.

Female.-Frons at least one-third of the head-width and less than 1.5 as long as wide, not so distinctly striated as in male. Ovipositor as in polita Say.

Length $4-4.5 \mathrm{~mm}$.

Type.-Male, allotype, and one male paratype, Santa Clara, Cal. (Baker); one male, San Diego, Cal. (Harkins collection); one male, Palo Alto, Cal., August 3. Type in collection of University of California.

\section{Lonchæa bakeri, sp. $\mathrm{n}$.}

Female.-Glossy black, without distinct bluish tinge, the frons greenish blue anteriorly. Face and cheeks with whitish pruinosity; frons shining upper, orbits and ocellar triangle glossy; antennæ brownish black. Legs black, tarsi yellow, apical two segments darkened. Wings clear, veins yellow. Calyptræ and their fringes white.

Frons at vertex one-third of the head-width, not narrowed anteriorly, its length about 1.5 of its width, surface microscopically striate on upper half granulose anteriorly, with sparse hairs; upper orbits almost imperceptibly striate; third antennal segment not twice as long as wide; face not carinate, cheek with 3 or 4 strong, but not very long bristles on lower margin anteriorly. A strong bristle on upper margin of mesopleura a little behind spiracle and considerably cephalad of the vertical series at anterior margin of haired area; scutellum without hairs between apical bristles. Ovipositor not broad, the apical hairs very short. Hind femora without antero-ventral bristles; anterodorsal setulæ on hind tibiæ stronger than usual. Veins 3 and 4 very slightly convergent apically. Fringes of calyptræ normal.

Length $3 \mathrm{~mm}$., exclusive of ovipositor.

Type--Chinangega, Nicaragua (F. C. Baker).

Named in honour of the collector.

This species is closely allied to albiceps Malloch, having the same armature of the mesopleura, and the same type of frons but without the transverse depression, and the calyptræ white, and venation different.

Type in collection of University of California.

\section{AN ADDITION TO BIBLIOGRAPHY ON AGRILUS (Coleop.).}

Through an oversight on our part, a recent paper of Burke's was omitted from the Agrilus bibliography, (Can. Ent., Sept., 1920, p. 204), and is given below.

Burke, Jour. Econ. Ent., Vol. 10, No. 3, pp. 325-332, 1917. Contains notes on food plants and habits of Agrilus angelicus Horn, A. niveiventris Horn, A. granulatus Say, A. anxius Gory, A. acutipennis Mann., A. politus Say. 